\title{
Analysis of Student Errors in Solving Mathematics Problems at Muhammadiyah Senior High School Special Program of Kottabarat Surakarta City
}

\author{
Ratna Herawati ${ }^{1}$, Ismiyati Marfuah ${ }^{2}$ \\ ${ }^{1}$ Prodi Teknik Komputer, STMIK AUB Surakarta, Jl. MW Maramis No 29, Cengklik, Banjarsari, Surakarta \\ ${ }^{2}$ SMA Muhammadiyah Program Khusus Kottabarat Surakarta, Jl. Pleret Raya, Sumber, Banjarsari, Surakarta \\ ratna.herawati@stmik-aub.ac.id
}

\begin{abstract}
Learning mathematics is a crucial part of education. Mathematics is one of the subjects feared by students. One of the problems in the object of mathematics study is the material for X class of Senior High School. Students of grade $\mathrm{X}$ are undergoing adaptation from the junior high school level to the high school level so that the findings of conceptual errors, calculations, and thinking patterns in problem-solving algorithms are often found. This also happened to the students of the Muhammadiyah Senior High School Special Program of Kottabarat Surakarta. In connection with the above problems, the author analyzes student errors in solving math problems at the Muhammadiyah senior high school special program of Kottabarat Surakarta.This study aims to find out errors, causes of error, and alternative problem solving related to students' errors in solving math problems. This research is qualitative descriptive research. The research subjects were taken by sampling purposes. they are three students of class X. The research method used is qualitative research methods, data collection techniques used in this study are test methods, interview methods, and documentation methods. The research instrument is the main instrument, namely the researcher himself and the auxiliary instruments in the form of test sheets, interview guidelines, and field notes. The data analysis technique uses data reduction, data presentation, and data verification, and triangulation techniques. The results of this study indicate that the types of errors that did most often made are errors in understanding questions that were 9 times, process skills errors and coding errors were 6 times, and reading errors were never made by research subjects.
\end{abstract}

Keywords: analysis, student errors, mathematics

\begin{abstract}
Abstrak
Pembelajaran matematika menjadi salah satubagian penting dalam pendidikan. Matematika merupakan salah satu mata pelajaran yang ditakuti oleh siswa. Salah satu permasalahan dalam kajian matematika adalah materi kelas X SMA. Pesertadidik kelas $\mathrm{X}$ mengalami adaptasi dari jenjang sekolah menengah pertama ke jenjang menengah atas, sehingga temuan kesalahan konsep, perhitungan dan alur berpikir dalam algoritma penyelesaian soal sering ditemukan. Hal terjadi pada peserta didik SMA Muhammadiyah Program Khusus Kottabarat Surakarta. Berkaitan dengan permasalahan di atas penulis melakukan Analisis Kesalahan Siswa Dalam Menyelesaikan Soal Matematika di SMA Muhammadiyah Program Khusus Kottabarat Surakarta. Penelitian ini bertujuan mengetahui kesalahan, penyebab kesalahan, serta alternative pemecahan masalah berkaitan dengan kesalahan pesertadidik dalam menyelesaikan soal matematika. Penelitian ini adalah penelitian deskriptif kualitatif. Subyek penelitian diambil dengan purposes sampling yaitu sebanyak tiga siswa kelas X. Metode penelitian yang digunakan adalah metode penelitian kualitatif, teknik pengumpulan data yang digunakandalampenelitianiniadalahmetodetes, metodewawancara dan metodedokumentasi. Instrument penelitian ini adalah instrument utama yaitu peneliti dan instrument bantu berupa lembartes, pedoman wawancara, dan catatan lapangan. Teknik analisis data menggunakan reduksi data, penyajian data, dan verifikasi data serta triangulasi teknik. Hasil penelitian ini menunjukkan bahwa jenis kesalahan yang paling sering dilakukan adalah kesalahan memahami soal yaitu 9 kali, kesalahan keterampilan proses dan kesalahan pengkodean yaitu 6 kali, dan kesalahan membaca tidak pernah dilakukan oleh subyek penelitian.
\end{abstract}

Kata kunci: analisis, kesalahan siswa, matematika

Copyright (c) 2021 Ratna Herawati, IsmiyatiMarfuah

$\triangle$ Corresponding author: Ratna Herawati

Email Address: ratna.herawati@stmik-aub.ac.id (Jl. MW Maramis No.29 Cengklik, Banjarsari, Surakarta)

Received 27 July 2021, Accepted 23 August 2021, Published 04 November 2021

\section{INTRODUCTION}

Learning activities are carried out with class assessment, namely by providing feedback on the learning process and immediately being able to correct it when obstacles arise, providing valuable 
information about how students learn and encouraging the understanding that teaching is a formative process that involves continuous feedback (Budiyono, 2015). One of the difficulties of students in learning mathematics is understanding the sentence questions (Aljupri, 2021). Errors were deviations made in completing a predetermined job (Mauliandri, 2020). The causes of students often making mistakes in solving math problems can be seen from several things, including a lack of understanding of the prerequisite material and the subject matter studied, lack of mastery of mathematical language, misinterpreting or applying formulas, miscalculations, lack of accuracy or forgetting concepts (Ramalisa, 2014). In the object of the study of mathematics, one of the problems is the material for $\mathrm{X}$ grade of Senior High School. The students of grade X are undergoing adaptation from the junior high school level to the high school level so that the findings of conceptual errors, calculations, and thinking patterns in problem-solving algorithms are often found. This problem also happened to students of Muhammadiyah High School Special Program for Surakarta City. Based on the result of the tests carried out in this case, the material tested is a composition function and an inverse function. Most of the students have difficulty solving mathematics problems. From the test results, errors were also found in problem-solving, beginning misinterpreting the meaning of the sentences in the questions, errors in the order of completion, and errors in calculations.

Based on the Newman method, student errors can be classified, namely reading errors, comprehension errors, transformation errors, process skill errors, and enencoding errors (Pratama, 2017). The types of errors made by students in solving quadratic function questions include conceptual errors, principle errors, and calculation errors (Isfan, 2018). Types of errors made by students include conceptual errors, procedural errors, and errors in understanding questions (Hadiyanto, 2020). From the results of the student error analysis, it was found that the errors made by students were conceptual error, procedural error, and technical error (Aulia, 2021). This study aims to analyze student errors in solving math problems using the Newman method. The material used as the analytical test is the composition function and the inverse function. This research refines previous research with the latest in online learning models using digital learning media.

\section{METHOD}

This research is a descriptive study where all data are collected based on facts obtained in the field. Qualitative descriptive research looks more at the characteristics, quality, and relationships between activities. Descriptive research is research that does not provide action, manipulation, or make a change to the independent variable, but describes the actual situation (Sukmadinata, 2010). Qualitative research is research conducted with natural objects that develop as they are not manipulated by researchers (Sugiyono, 2014). Qualitative research methods are research methods used to examine natural conditions, where the researcher is the key instrument, data collection techniques are done by triangulation, data analysis is inductive, and qualitative research results emphasize meaning rather than generalization (Sugiyono, 2015). 
The research subjects analyzed were selected based on sampling purposes, namely to find out student errors in solving math problems. Students are selected with high, medium, and low academic ability. It aims to be able to find objectivity and can be used as a benchmark for the success of a learning process. The subjects of the study were students of class X Social Sciences at SMA Muhammadiyah Special Program for Kotatabarat Surakarta in the academic year 2020/2021 consisting of twenty-five students and three of them as respondents. The data sources used in this study were mathematics teachers and students of class X Social Studies at SMA Muhammadiyah Special Program of Kottabarat Surakarta for the 2020/2021 academic year. As for the data collection technique using a written test which aims to determine and organize students' abilities in working on questions, and interviews are one of the data collection techniques carried out by direct question and answer with data sources. Interviews were conducted to dig up information about something needed for researchers. In this study, interviews were conducted to ascertain the things that caused students to make mistakes in solving math problems. This study uses non-statistical data analysis techniques because this type of research is a qualitative descriptive study so that the data that appears is in the form of words that describe the results of the research. Data analysis techniques used are data reduction, data presentation, and verification.

The study was conducted with preliminary discussions between researchers, partner teachers, and school principals regarding the initial conditions found in the school so that the findings were carried out as initial conditions. Then the teacher provides material and questions to be analyzed, from this analysis it was found that students' errors in solving math problems, classification of errors, causes of errors, and how to evaluate students' mistakes so that there was justification. The description of the research activities is presented in the form of the following flowchart:

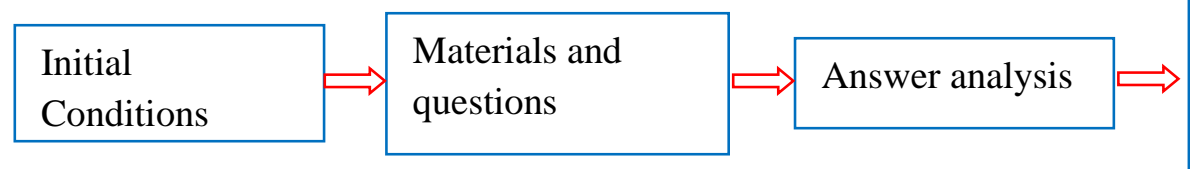

Conditions

questions

1. Student error classification

2. Cause of student error

3. Evaluation

Figure 1. Research Flowchart Starting from The Initial Conditions to The Stage After the Answer Analysis

As for the analysis of students' answers, an error analysis according to Newman or Newman's Error Analysis (NEA) was used. Newman's Error Analysis in teaching can be a good diagnostic tool to assess and analyze the difficulties experienced by students (Pramesti, 2020). NEA is grouped into five sections as shown in the following table.

Table 1. Type of Errors According to Newman

\begin{tabular}{|l|l|}
\hline \multicolumn{1}{|c|}{ Error type } & \multicolumn{1}{c|}{ Indicator } \\
\hline Reading error & $\begin{array}{l}\text { Students cannot read the keywords or symbols } \\
\text { in the problem }\end{array}$ \\
\hline
\end{tabular}




\begin{tabular}{|c|c|}
\hline Comprehension error & $\begin{array}{l}\text { - Students have been able to read the words, but } \\
\text { do not understand the overall meaning of the } \\
\text { words. } \\
\text { - Students are not able to understand what is } \\
\text { asked completely. }\end{array}$ \\
\hline Transformation error & $\begin{array}{l}\text { - Students understand known questions, but for } \\
\text { the possibility of identifying operations, or the } \\
\text { sequence of operations is still wrong. } \\
\text { - Students are not able to make mathematical } \\
\text { models from the information presented. } \\
\text { - Students do not know what formulas are used } \\
\text { to solve problems. } \\
\text { - Students do not know the arithmetic operation } \\
\text { to be used. }\end{array}$ \\
\hline Process skill error & $\begin{array}{l}\text { - The student identifies the appropriate } \\
\text { operation, or sequence of operations, but does } \\
\text { not know the procedures required to complete } \\
\text { this operation accurately. } \\
\text { - Students do not know the procedures or steps } \\
\text { used to solve the problem. } \\
\text { - Students are not able to carry out the procedures } \\
\text { or steps used appropriately. }\end{array}$ \\
\hline Encoding error & $\begin{array}{l}\text { - Students look for the correct solution to the } \\
\text { problem, but cannot express this solution in } \\
\text { written form. } \\
\text { - Students are not able to find the final result } \\
\text { according to the procedures or steps used. } \\
\text { - Students cannot show the final answer from } \\
\text { solving the problem. } \\
\text { - Students cannot code according to the } \\
\text { conclusions referred to in the question. }\end{array}$ \\
\hline
\end{tabular}

\section{RESULT AND DISCUSSION}

\section{The First Research Subject}

\section{The Error Analysis of S1 For Number 1}

The error analysis of S1 for number 1 showed at the figure 2 below

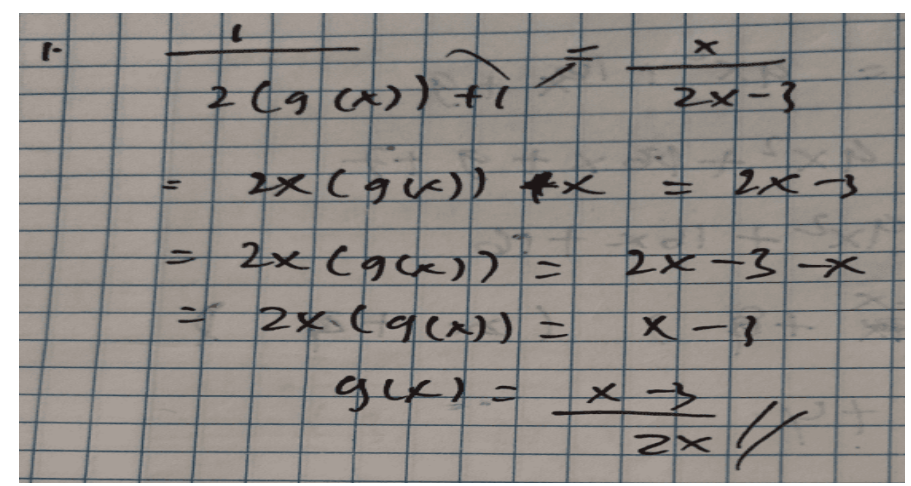

Figure 2. The answer of S1 for question number 1 
S1 did not write down the identity of the question which consisted of what was known and what was asked. S1 only writes answers directly to the problem-solving algorithm. This is not wrong, but less precise algorithmically solving problems in mathematics. Conceptually, the answer must be coherent starting from what is known, what is being asked, then only to the flow of answers. This may be because students have misunderstood.

\section{The Error Analysis of S1 For Number 2}

The error analysis of S1 for number 2 showed at the figure 3 below
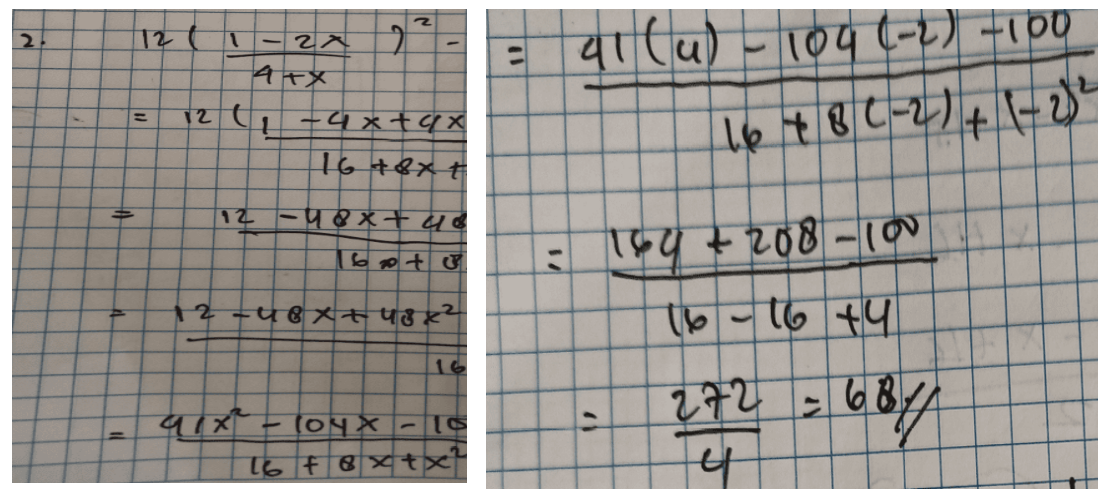

Figure 3. The answer of S1 for question number 2

In question number 2, the error was the same as that made in number 1, S1 did not write down the identity of the question which consisted of what was known and what was asked. S1 only writes answers directly to the problem-solving algorithm. This is not wrong, but less precise algorithmically solving problems in mathematics. Conceptually, the answer must be coherent starting from what was known, what was being asked, then only to the flow of answers. This problem happened because students have misunderstood.

\section{The Error Analysis of S1 For Number 3}

The error analysis of S1 for number 3 showed at the figure 4 below

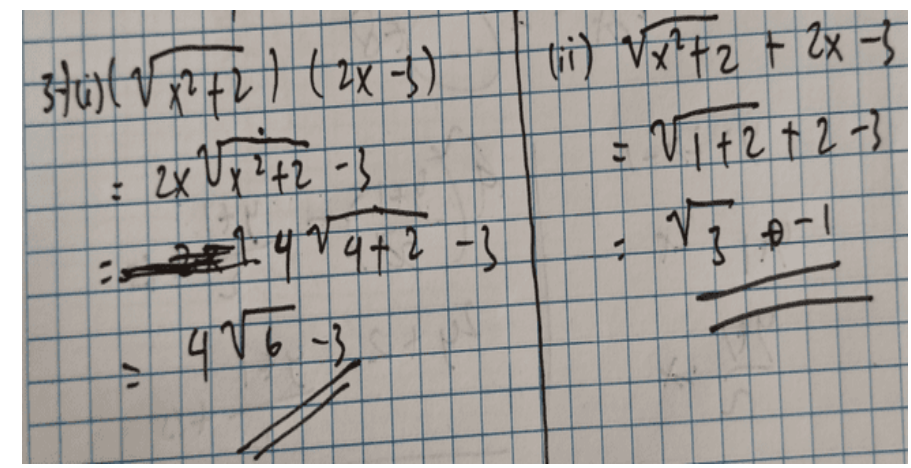

Figure 4. The answer of S1 for question number 3

In number 3, S1 made an error starting from not writing down what was known, what was asked, and also an error occurred during the problem-solving algorithm, namely determining $(f . g)(2)$. Step S1 
in completing $(f . g)(2)$ is to multiply first $f(x)$ with $g(x)$. In this step, S1 made an error in the algebraic multiplication operation between $f(x)=\sqrt{x^{2}+2}$ and $g(x)=2 x-3$. An error occurred in the distributive property of multiplication over addition. Algebraic multiplication form $\left(\sqrt{x^{2}+2}\right) \cdot(2 x-3$ ) means $2 x$ multiplied by $\sqrt{x^{2}+2}$ and then reduced by multiplication between 3 and $\sqrt{x^{2}+2}$. But S1 only multiplies $2 x$ with $\sqrt{x^{2}+2}$ then the result reduced by 3 . This means that the next step is wrong. The possibility of this error occurs because students experience transformation errors.

\section{The Second Research Subject}

\section{The Error Analysis of S2 For Number 1}

The error analysis of S2 for number 1 showed at the figure 5 below

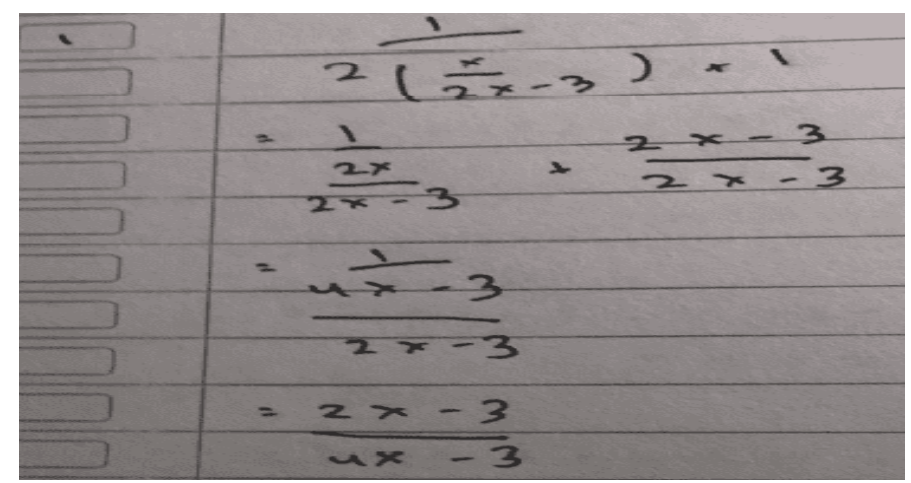

Figure 5. The Answer of S2 For Question Number 1

In question number 1, S2 made several mistakes, begin from not writing down what was known and what was asked in the question, there were also errors in the problem-solving step. Problem number 1 was to determined $g(x)$ from what was known in problem, they were $f(x)$ and $(f 0 g)(x)$. The first step was to formed the equation of the function $(f O g)(x)$. The next step was to substitute $g(x)$ in the form of the function equation $f(x)$. Because $(f O g)(x)$ was a function of $g(x)$ in $f(x)$, it means that the function $g(x)$ was substituted in the function formulation $f(x)$, but on the answer sheet, S2 substitutes $(f \circ g)(x)$ in the function formulation $f(x)$. This mistake happen because $\mathrm{S} 2$ made a transformation error with the indicator that the students did not know the steps to solve the problem, so that the next step was the wrong answer and did not answer in question number 1 , namely determining $g(x)$ from what was known in questions $\mathrm{f}(\mathrm{x})$ and $(\mathrm{f} 0 \mathrm{~g})(\mathrm{x})$. This error can be minimized by providing students with an understanding of how to solve the problem through procedures or algorithms for solving mathematical problems correctly and comprehensively.

\section{The error analysis of $\mathbf{S 2}$ for number 2}

The error analysis of $\mathrm{S} 2$ for number 2 showed at the figure 6 below 


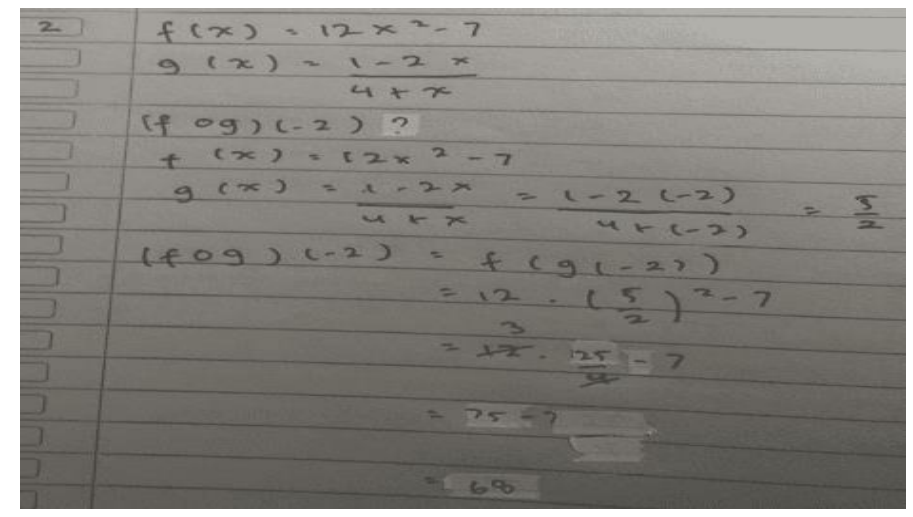

Figure 6. The Answer of S2 for Question Number 2

In question number 2, S2 made several mistakes including S2 writing down what was known in the question but did not provide information with the word "known", S2 wrote down what was asked in the question but did not provide information "asked". S2 goes to the problem-solving step by determining the value of $g(-2)$. The step to determine the value of $g(-2)$ is correct, it's just that when S2 writes the formula $g(x)$, then to determine the value of the function $g$ for $x=-2$ is to write $g(2)$ first before substituting $\mathrm{x}=-2$ on $\mathrm{g}(\mathrm{x})$. the next step also found an error. That is when $\mathrm{S} 2$ determines the value of $(f 0 g)(-2)$. To determine the value of $(f 0 g)(-2)$, meaning that we substitute the value of $\mathrm{g}(-2)$ into the $\mathrm{f}(\mathrm{x})$ formulation, in this step S2 does not write down the value $g(-2)=\frac{5}{2}$ in the $f(x)$, the correct step is after writing $(f 0 g)(-2)$, the next step is to equate with $\mathrm{f}(\mathrm{g}(-2))$ then equate to $f\left(\frac{5}{2}\right)$, and then substitute it to the formula $f(x)$ for $x=\frac{5}{2}$. This error occurred probably because S2 made a processing error where there was one process that was skipped so that the problem-solving algorithm was incomplete.

\section{The Error Analysis of $\mathbf{S 2}$ for Number 3}

The error analysis of S2 for number 3 showed at the figure 7 below

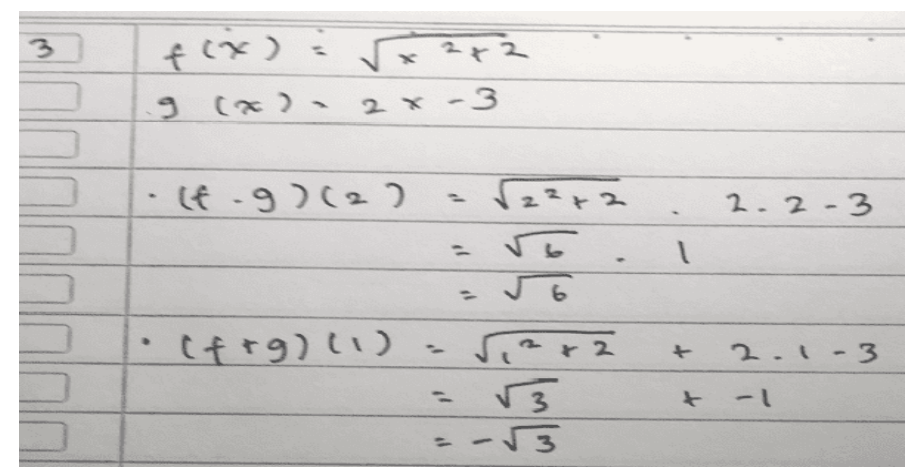

Figure 7. The Answer of S2 For Question Number 3 
In question number 3, S2 made a mistake by not verbally writing down what is known, S2 only wrote down the formulas $f(x)$ and $g(x)$. in the problem solving algorithm, S2 made an error including, in the multiplication operation $(f g)(2)$, S2 should first explain that $(f g)(2)=f(2) \cdot g(2)$ and then substitute $x$ $=2$ into in the function formula $f(x)$ and $g(x)$. for the operation $(f+g)(1)$, apart from the error S2 did not specify beforehand $(f+g)(1)=f(1)+g(1)$, S2 also made an error in the result of the operation where it should $\sqrt{3}+(-1)=\sqrt{3}-1$, but $S 2$ writes the result of the operation is $\sqrt{3}+(-1)=-\sqrt{3}$. This error is possible because S2 does not understand the operation of integers and irrational numbers, resulting in an error in the final result of the answer to question number 3. This can be minimized by reminding the concept of numbers and rational number operations, the form of roots or powers of fractions along with root number operations. or fractional power to students, making it easier for students to calculate the fractional rank.

\section{The Third Research Subject}

\section{The Error Analysis of S3 for Number 1}

The error analysis of S3 for number 1 showed at the figure 8 below

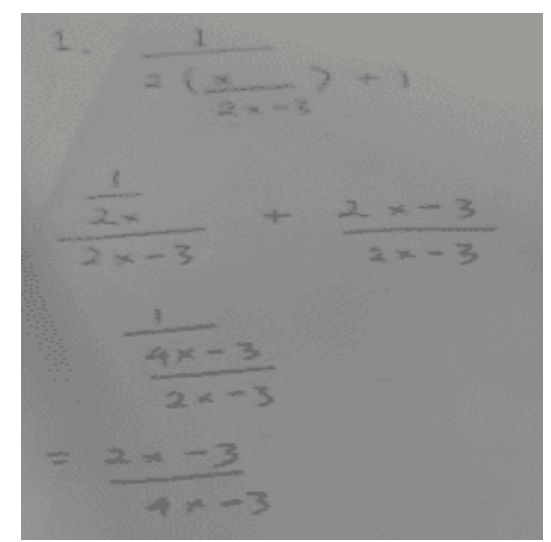

Figure 8. The Answer of S3 for Question Number 1

In question number 1, S3 made several mistakes in solving the problem. First, S3 does not write down what is known in the problem, and what is asked in the question. Second, S3 made an error in the algorithm for solving problem number 1 , question number 1 was to determine $\mathrm{g}(\mathrm{x})$ from what is known in the problem, namely $\mathrm{f}(\mathrm{x})$ and $(\mathrm{f} 0 \mathrm{~g})(\mathrm{x})$. This step can be solved by substituting $\mathrm{g}(\mathrm{x})$ into the $\mathrm{f}(\mathrm{x})$ formulation and then equating it with the ( $\mathrm{f} 0 \mathrm{~g})(\mathrm{x})$ formulation. in this case, $\mathrm{S} 3$ made an error that should have $\mathrm{g}(\mathrm{x})$ substituted into $\mathrm{f}(\mathrm{x})$ and then equated it with the formulation ( $\mathrm{f} 0 \mathrm{~g})(\mathrm{x})$, but S3 substituted the formulation ( $\mathrm{f} 0 \mathrm{~g})(\mathrm{x})$ into $\mathrm{f}(\mathrm{x})$, even though the form is still a function equation ( $0 \mathrm{~g})(\mathrm{x})$. This is what causes the next step to be incorrect. This error occurred, perhaps because S3 did not understand the concept of the composition function itself. In addition, students have not been able to distinguish the form of the composition function between ( $0 \mathrm{~g})(\mathrm{x})$ and $(\mathrm{g} 0 \mathrm{f})(\mathrm{x})$. how to solve the composition function between $\mathrm{f} 0 \mathrm{~g})(\mathrm{x})$ and $(\mathrm{g} 0 \mathrm{f})(\mathrm{x})$. so that in this case the teacher needs to re-explain the concept of the 
composition function to students to minimize the same mistakes as those made by $\mathrm{S} 3$ in solving problem number 1 above.

\section{The Error Analysis of S3 for Number 2}

The error analysis of S3 for number 2 showed at the figure 9 below

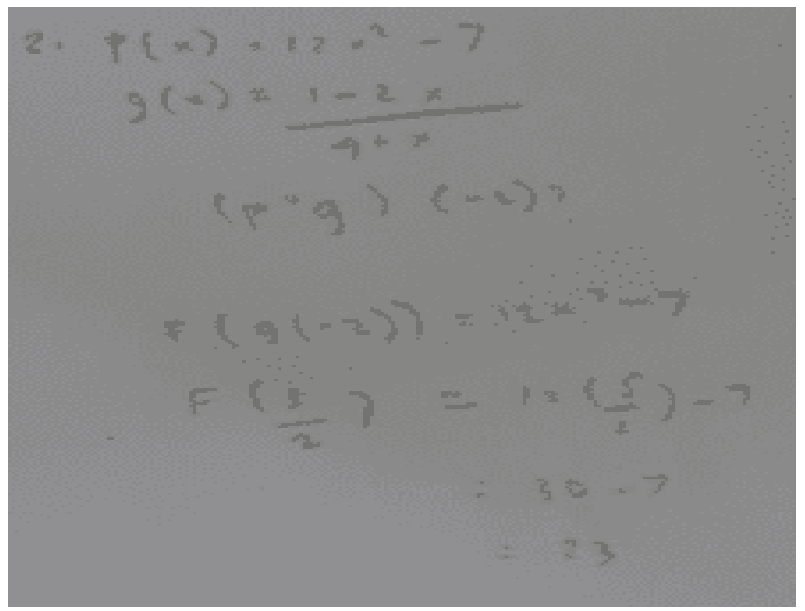

Figure 9. The Answer of S3 for Question Number 2

In solving problem number 2, S3 made several mistakes including, the first error was even though he wrote $\mathrm{f}(\mathrm{x})$ and $\mathrm{g}(\mathrm{x})$ also (fOg)(-2), but S3 did not verbally write "known", "asked", and "answer" so that in the mathematical problem-solving algorithm this becomes less comprehensive. The second mistake that S3 made in solving problem number 2 was in the step of determining the value of (fog)(2 ), after writing $\mathrm{f}(\mathrm{g}(-2))$ which was nothing but the form of ( $\mathrm{fOg})(-2)$, it should be S3 first write the value of $g(-2)$ into the function $f$, then substitute it into the $f(x)$ formulation, but in the solution step, S3 immediately substitutes $\left(\frac{5}{2}\right)$ which is none other than the value of $g(-2)$ into the $f(x)$ formulation, whereas to get the value of $g(-2), S 3$ must first calculate by substituting $x=(-2)$ into the $g(x)$ formulation, but S3 immediately found the value of $\mathrm{g}(-2)$ without any prior calculations, so that in the case of the process it is necessary to suspect that the S3 answer is the result of S3's work or is the result of asking a classmate. The third mistake that S3 made in solving problem number 2 was in the operation of calculating the power of two with fractional base numbers. On step $12\left(\frac{5}{2}\right)^{2}-7$ the result should be $12\left(\frac{25}{4}\right)-7$ so that the result $75-7$ is 68 . However, $\mathrm{S} 3$ finds the calculation result $30-7$, the value 30 is obtained from the result of the operation 12 divided by 2 , the result is multiplied by 5 , in this case, $\mathrm{S} 3$ does not square the fractions in brackets. So, the final result is also incorrect. In this case, S3 encountered an error in the calculation. 


\section{The Error Analysis of S3 for Number 3}

The error analysis of $\mathrm{S} 3$ for number 3 showed at the figure 10 below

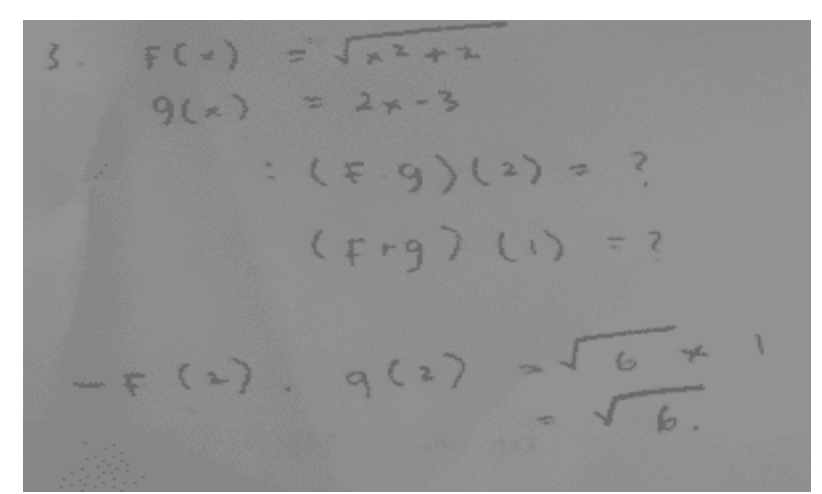

Figure 10. The Answer of S3 for Question Number 3

In solving problem number 3, S3 made several mistakes, including, the first mistake made by S3 in solving question number 3 was that even though he wrote $f(x)$ and $g(x), S 3$ did not write known, asked, answered. The second mistake that S3 made in solving problem number 3 was when determining the value of $f(2)$. $g(2)$, S3 directly writes the value of $f(2)$ multiplied by the value of $g(2)$ which should be calculated first and substituted into the multiplication operation. Although the answer is correct, the algorithm is incomplete. The third mistake that $\mathrm{S} 3$ made in solving problem number 3 was not answering $(\mathrm{f}+\mathrm{g})(1)$ this indicates that $\mathrm{S} 3 \mathrm{did}$ not understand the addition operation on two functions.

\section{Discussion}

In general, it can be seen that all research subjects made mistakes in solving the given math problems. Although not all the questions they do are wrong. But there are some errors so that the answer becomes less than perfect. The following is a discussion of some of the mistakes made by research subjects:

\section{Misunderstood The Question}

In question number 1 , the three research subjects misunderstood the question. In question number 2 , the three research subjects misunderstood the question. As in question number 3, the three research subjects misunderstood the question. The causes of research subjects misunderstood the questions were as follows: 1) Forget to write down what is known, and the means in the questions. 2) The subjects did not accustom to writing down what is known and the means in the question. 3) The subject is Confused about what to write about what is known, and what is asked in the question. 4) Does not understand what is known and what is being asked in the question. 5) Difficulty finding what is known and what is being asked in the question. Lack of accuracy in problem-solving steps.

\section{Transformation Error}

There were findings of transformation errors in solving the problems given, namely errors made by subjects 2 and 3 in solving problem number 1. transformation errors also occurred in subject 3 in solving questions number 2 and question number 3. This can be seen from the results of interviews, 
subjects 2 and 3 do not understand the steps that must be taken after what is known in the problem. Subjects 2 and 3 also did not understand what method should be used as a step in determining the solution to the questions given.

\section{Process Skill Error}

In question number 1, process skill errors were made by subjects 2 and 3. In question number 2, process skills errors were made by subject 3, while in question number 3, process skills errors were made by the three research subjects. The causes of research subjects making process skills errors are as follows: 1) The result of the error in the previous step. 2) Lack of accuracy in the calculation process.

3) Do not understand the concept of composition. 4) Do not understand the concept of calculation used.

\section{Encoding Error}

In question number 1, encoding errors were made by subjects 2 and 3. In question number 2, encoding errors were made by subject 3 , while in question number 3 , encoding errors were made by the three research subjects. The causes of research subjects making encoding errors are as follows: 1) As a result of previous mistakes. 2) Do not understand what is being asked in the question. 3) Get used to not concluding the final answer. To find out in more detail the errors of research subjects in solving math problems based on the Newman method, the above discussion is presented in the following table:

Table 2. The Error of The Research Subject In Terms of The Type of Error According to Newman

\begin{tabular}{|c|c|c|c|c|c|}
\hline \multirow{2}{*}{ Error Type } & \multirow{2}{*}{ Subject } & \multicolumn{3}{|c|}{ Question Number } & \multirow{2}{*}{ Number of Errors } \\
\hline & & 1 & 2 & 3 & \\
\hline \multirow[t]{3}{*}{ Reading } & 1 & $\mathrm{X}$ & $\mathrm{x}$ & $\mathrm{x}$ & 0 \\
\hline & 2 & $\mathrm{X}$ & $\mathrm{x}$ & $\mathrm{x}$ & 0 \\
\hline & 3 & $\mathrm{X}$ & $\mathrm{x}$ & $\mathrm{x}$ & 0 \\
\hline \multicolumn{2}{|l|}{ Number of errors } & 0 & 0 & 0 & \\
\hline \multirow{3}{*}{$\begin{array}{l}\text { Comprehension } \\
\text { error }\end{array}$} & 1 & $\mathrm{~V}$ & $\mathrm{~V}$ & $\mathrm{v}$ & 3 \\
\hline & 2 & $\mathrm{~V}$ & $\mathrm{v}$ & $\mathrm{v}$ & 3 \\
\hline & 3 & $\mathrm{~V}$ & $\mathrm{v}$ & $\mathrm{v}$ & 3 \\
\hline \multicolumn{2}{|l|}{ Number of errors } & 3 & 3 & 3 & \\
\hline \multirow[t]{3}{*}{ Transformation } & 1 & $\mathrm{X}$ & $\mathrm{x}$ & $\mathrm{x}$ & 0 \\
\hline & 2 & $\mathrm{~V}$ & $\mathrm{X}$ & $\mathrm{x}$ & 1 \\
\hline & 3 & V & $\mathrm{v}$ & $\mathrm{v}$ & 3 \\
\hline \multicolumn{2}{|l|}{ Number of errors } & 2 & 1 & 1 & \\
\hline \multirow[t]{3}{*}{ Process skill } & 1 & $X$ & $\mathrm{x}$ & $\mathrm{v}$ & 1 \\
\hline & 2 & $\mathrm{~V}$ & $\mathrm{x}$ & $\mathrm{v}$ & 2 \\
\hline & 3 & $\mathrm{~V}$ & $\mathrm{~V}$ & $\mathrm{v}$ & 3 \\
\hline \multicolumn{2}{|l|}{ Number of errors } & 2 & 1 & 3 & \\
\hline \multirow[t]{3}{*}{ Coding } & 1 & $\mathrm{X}$ & $\mathrm{x}$ & $\mathrm{v}$ & 1 \\
\hline & 2 & $\mathrm{~V}$ & $\mathrm{X}$ & $\mathrm{v}$ & 2 \\
\hline & 3 & $\mathrm{~V}$ & $\mathrm{v}$ & $\mathrm{v}$ & 3 \\
\hline \multicolumn{2}{|l|}{ Number of errors } & 2 & 1 & 3 & \\
\hline
\end{tabular}

Information:

$\mathrm{v}$ : there is an error

$\mathrm{x}$ : no error

-: don't do the problem 
Based on table 2, it can be seen the number of errors made by each research subject in terms of the Newman method, as presented in table 3 below:

Table 3. The Number of Errors of Each Research Subject According to The Newman Method

Information:

\begin{tabular}{|l|c|c|c|}
\hline \multirow{2}{*}{ Error type } & \multicolumn{3}{|c|}{ Research subject } \\
\cline { 2 - 4 } & $\mathbf{1}$ & $\mathbf{2}$ & $\mathbf{3}$ \\
\hline Type 1 & 0 & 0 & 0 \\
\hline Type 2 & 3 & 3 & 3 \\
\hline Type 3 & 0 & 1 & 3 \\
\hline Type 4 & 1 & 2 & 3 \\
\hline Type 5 & 1 & 2 & 3 \\
\hline Number of errors & 5 & 8 & 12 \\
\hline
\end{tabular}

Type 1: reading error

Type 2: comprehension error

Type 3: transformation error

Type 4: process skill error

Type 5: encoding error

Based on table 3, it can be seen, there are errors in working on mathematical items using the Newman method, and are presented in table 4 below:

Table 4. The Number of Errors Per Item in Terms of The Type of Error According to The Newman Method

\begin{tabular}{|l|c|c|c|c|}
\hline \multirow{2}{*}{ Error type } & \multicolumn{3}{|c|}{ Question number } & \multirow{2}{*}{ Number of errors } \\
\cline { 2 - 4 } & $\mathbf{1}$ & $\mathbf{2}$ & $\mathbf{3}$ & \\
\hline Type 1 & 0 & 0 & 0 & 0 \\
\hline Type 2 & 3 & 3 & 3 & 9 \\
\hline Type 3 & 2 & 1 & 1 & 4 \\
\hline Type 4 & 2 & 1 & 3 & 6 \\
\hline Type 5 & 2 & 1 & 3 & 6 \\
\hline
\end{tabular}

Information:

Type 1: reading error

Type 2: comprehension error

Type 3: transformation error

Type 4: process skill error

Type 5: encoding error

From table 4 it can be seen, the type of error that is most often made is comprehension error, which is 9 times. This error occurs because students do not understand the information contained in the problem so that the information written by students is incomplete (Rahmawati, 2018). The second error 
that is often made is the type of process skill error and encoding error, which is 6 times. Conceptual errors were mistakes made by students because they did not understand the concept of the material (Putri Anggraini, 2020). Encoding errors occur when students have successfully reached the data processing stage but failed to write a final solution. This error occurs because students do not understand with the issues in question (Santoso, 2017). Reading errors were never made by the research subjects. Factors that cause student errors in mathematics include internal factors consisting of intelligence, physical weakness, and study habits. external factors include the environment and learning atmosphere (Nurianti, 2015).

\section{CONCLUSION}

Based on the results of research and discussion, the following conclusions can be drawn. First, the types of errors made by students in solving math problems in terms of Newman's method are as follows; 1) in solving math problems, research subjects misunderstood the problem. 2) there are research subjects who make transformation errors. 3) There are process skills errors made by research subjects in solving math problems. 4) there are encoding errors made by research subjects. Second, the causes of errors made by students in solving math problems based on Newman's method are described as follows; 1) Causes of misunderstood questions include forgetting to write down what is known and what was asked in the question because not accustomed about it. 2) The causes of transformation errors include lack of understanding of the steps and lack of understanding of what method should be used. 3) The causes of process skill errors include the result of errors in the previous step. 4) the cause of encoding errors is as result of mistakes made previously, not understanding what is being asked in the question, accustomed to not concluding the final answer.

\section{ACKNOWLEDGMENT}

This study was funded by Deputi Bidang Penguatan Riset dan Pengembangan, Kementerian Riset dan Teknologi/Badan Riset dan Inovasi Nasional Republik Indonesia through Skema Penelitian Dosen Pemula year 2021. We thanks to students and teacher of SMA Muhammadiyah Program Khusus Kottabarat Surakarta for their active participation.

\section{REFERENCES}

Aljupri. (2021). Teaching and learning process for mathematization activities: The case of solving maximum and minimum problems. Journal of Research and Advances in Mathematics Education, 6(2), 100-110. https://doi.org/10.23917

Aulia, J. (2021). Analisis Kesalahan Siswa dalam Menyelesaikan Soal Matematika Pada Materi Himpunan Kelas VII SMP/MT s. Jurnal Cendekia: Jurnal Pendidikan Matematika, 5(1), 484-500. https://doi.org/10.31004/cendekia.v5i1.503

Budiyono, B. (2015). Pengantar Penilaian Hasil Belajar. UNS Press. 
Hadiyanto, F. R. (2020). Analisis Kesalahan Siswa Kelas VII Dalam Menyelesaikan Soal Geometri.

$\begin{array}{llll}\text { MandalikaMathematics and 21-31. } & \text { Education }\end{array}$ http://dx.doi.org/10.29303/mandalika.v2i1.1741

Isfan, I. (2018). Analisis Kesalahan Dalam Menyelesaikan Soal-soal Fungsi Kuadrat Pada Siswa Kelas X3 SMA Negerai 1 Asera. Jurnal Penelitian pendidikan Matematika, 6(1), 43-56.

Mauliandri, R. (2020). Analisis Kesalahan Siswa Menurut Kastolan Dalam Menyelesaikan Soal Operasi Bentuk Aljabar Pada Siswa SMP. AXIOM Jurnal Pendidikan \& Matematika, 9(2), 107-123. https://doi.org/10.30821/axiom.v9i2.7687

Nurianti, E. (2015). Aanalisis kesalahan Siswa Dalam Menyelesaikan Soal Matematika Materi Pecahan Bentuk Aljabar Di Kelas VIII SMP. jurnal Pendidikan dan pembelajaran Khatulistiwa, 4(9). https://jurnal.untan.ac.id/index.php/jpdpb/article/view/11206/10636

Pramesti, T. (2020). Analisis Kesalahan Siswa Berdasarkan Prosedur Newman Dalam Menyelesaikan Soal Cerita Materi Pecahan Pada Kelas Iv Sd Negeri Manyaran 02 Semarang. Elementary School Jurnal Pendidikan dan Pembelajaran Ke-SD-an, Special. https://doi.org/10.31316/esjurnal.v1i1

Pratama, A. P. (2017). Analisis Kesalahan Siswa Dalam Menyelesaikan Soal Matematika Materi Statistika. Ekuivalen-Guruan Matematika Jurnal Universitas Muhammadiyah Purworejo. http://ejournal.umpwr.ac.id/index.php/ekuivalen/article/view/3899

Putri Anggraini, Y. (2020). Analisis Kesalahan Siswa Dalam Menyelesaikan Soal Persamaan Kuadrat Pada Siswa Kelas IX SMP N 2 Bangking Kota. AXIOM Jurnal Pendidikan \& Matematika, 9(2), 210-223. https://doi.org/10.30821/axiom.v9i2.7682

Rahmawati, D. (2018). Analisis Kesalahan Siswa Dalam Menyelesaikan Soal Cerita Program Linear Dengan Prosedur Newman. Jurnal Elektronik Pembelajaran Matematika, 5(2), 173-185.

Ramalisa, Y. (2014). Analisis Pengetahuan Prosedural Siswa Tipe Kepribadian Sensing Dalam Menyelesaikan Soal Materi Sistem Persamaan Linear Dua Variabel. Edumatica: Jurnal Pendidikan Matematika, 4(1), 30-36.

Santoso, S. (2017). Error Analysis Of Students Working About Word Problem Of Linear Program With NEA Procedure. IOP Publishing, 1-8. https://doi.org/10.1088/1742-6596/855/1/012043

Sugiyono, S. (2014). Metode penelitian pendidikan. Alfabeta.

Sugiyono, S. (2015). Metode Penelitian pendidikan. Alfabeta.

Sukmadinata, S. (2010). Metode Penelitian Pendidkan. Remaja Rosdakarya. 